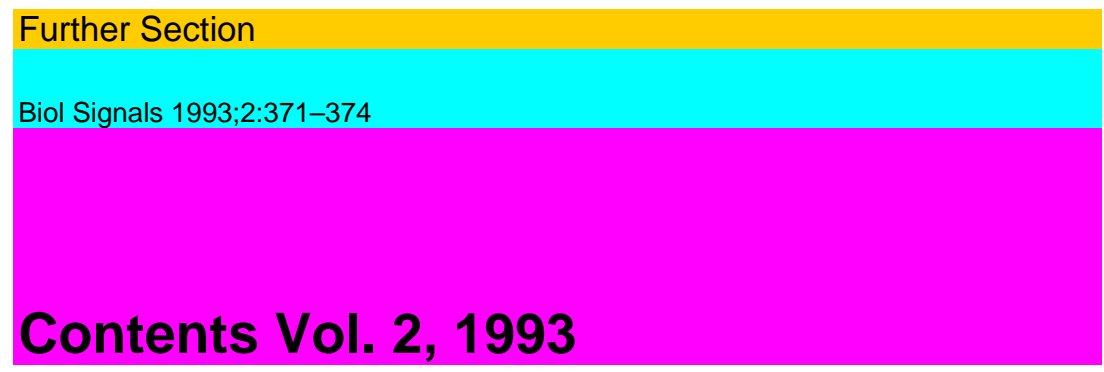

\title{
BioloqlcAl SiqNAls
}

Editors-in-Chief

\section{Editorial Board}

S.F. Pang, Hong Kong

T. Fujita, Niigata

P.A. Ward, Ann Arbor, Mich.

D.R. Alexander, Cambridge

L. Birnbaumer, Houston, Tex.

P. Bock, Vienna

G.M. Brown, Toronto

R.M. Buijs, Ottawa

D. Cantrell, London

D.P. Cardinali, Buenos Aires

S.H.H. Chan, Taipei

Y.S. Chan, Hong Kong

S. Cockcroft, London

M. Ebadi, Omaha, Nebr.

J.C. Fantone, Ann Arbor, Mich.

S.J. Fidone, Salt Lake City, Utah

J.B. Furness, Parkville

L.J. Garey, London 
G.H. Greeley, Jr.,

Galveston, Tex. D. Grube, Hannover T.D. Hexum, Omaha, Nebr.

T. Hokfelt, Stockholm J.-S. Hong,

Research Triangle Park, N.C.

T. Kanno, Sapporo M. Karasek, Lodz KS.L. Lam, Hong Kong

L.-I. Larsson, Copenhagen D. LeRoith, Bethesda, Md. P.C.K.

Leung, Vancouver A.Y.C. Liu, Piscataway, N.J. P.J. Magistretti, Lausanne L. Niles, Hamilton S.J. Peroutka,

San Francisco, Calif. P. PeVet, Strasbourg KK. Pun, San

Francisco, Calif. R.J. Reiter, San Antonio, Tex. A. Sato, Tokyo

L.A. Sklar,

Albuquerque, N. Mex. F. Sundler, Lund G.S. Wasserman, Lafayette, Ind. N. Yanaihara, Shizuoka M.J. Zigmond, Pittsburgh, $\mathrm{Pa}$.

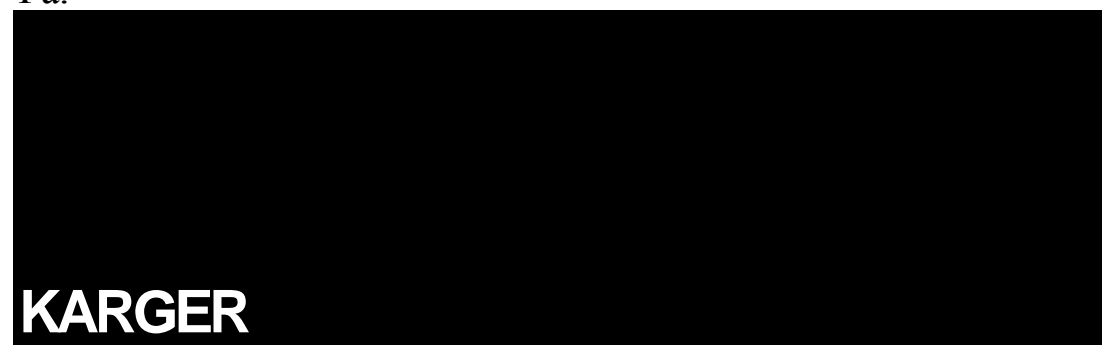

Contents Vol. 2,1993

No. 1

No. 2

Review

Cytosolic Calcium Oscillators: Critical Discus-

sion and Stochastic Modelling Kraus, M.; Wolf, B.

Original Papers

Release of Dopamine from Carotid Sinus Nerve $\quad 16$

Fibers Innervating Type I Cells in the Cat

Carotid Body

Almaraz, L.; Wang, Z.-Z.; Stensaas, L.J.; Fidone, S.J.

Effects of Guanosine 5'-0-(3-Thiotriphosphate) 27 on 2-[25 I]Iodomelatonin Binding in the Chicken Lung, Brain and Kidney: Hypothesis of Different Subtypes of High Affinity Melatonin Receptors Pang, S.F.; Ayre, E.A.; Poon. A.M.S.; Pang, C.S.; Yuan, H.; Wang, Z.P.; Song, Y.; Brown, G.M.

Opposite Effect of Superoxide Dismutase,

37

L-Axginine Analogues, Methylene Blue and Desferal: Suppression of HistamineInduced and Stimulation of Serotonin-Induced Paw Edema in Mice Oyanagui, Y.; Sato, S.

Simultaneous, Continuous, On-line and Real- 45 Time Spectral Analysis of Multiple Physiologic Signals by a Personal-Computer-Based Algorithm Kuo, T.B.J.; Shyr, M.-H.; Chan, S.H.H.

Review

Neuronal Communication Mayer, E.A.

57

Original Papers 
Localization of Prostaglandin G/H Synthase

77

Gene Expression in Rat Brain by in situ Hybridization Li, S.-R.; Wu, K.K.; Anggard, E.; Ferns, G.

Protein Kinase $\mathrm{C}$ as a Multi-Targeted Feedback 84 Inhibitor Regulating the $\mathrm{Ca}^{2+}$ Responses to Chemotactic Peptide Stimulation in the Murine Macrophage Cell Line PU5-1.8 Kong, S.K.; Choy, Y.M.; Lee, C.Y.

Cross-Correlation Study of Synaptic Input Distri- 95 bution Inside the Buccal Ganglion of a Gastropod Mollusk Fiore, L.; Geppetti, L.; Musio, C.

Effects of Chronic Captopril Treatment on the 106 Electrical-MicrostimulationInduced Blood Pressure Changes and Electrophysiological Properties of Cardiovascular Neurons in the Rostral Ventrolateral Medulla of the Spontaneously Hypertensive Rat Chan, R.K.W.; Chan, Y.S.; Wong, T.M.

No. 3

No. 4

Original Papers

Apotransferrin Can Elevate Intracellular Free 117 Calcium Ion and Stimulate Mitogenesis in Human Leukemic HL60 Cells Leung, Y.M.; Zhu, W.-H.; Loh, T.T.

Enhanced Generation of 0,by HumanNeutro- 126 phils via a Complement iC3b/Mac-1 Interaction Vaporciyan, A.A.; Ward, PA.

Myenteric and Submucosal Plexuses of the Con- 136 genital Aganglionosis Rat (Spotting Lethal) as Revealed by Scanning Electron Microscopy Nagahama, M.; Tsutsui, Y.; Ozaki, T.; Hama, K.

Differential Effects of Short Photoperiod on

$2-\left[{ }^{125} \mathrm{I}\right]$ Iodomelatonin Binding in the Testis and

Brain of Quail

Pang, S.F.; Cheng, K.M.; Pang, C.S.; Wang, Z.P.;

Yuan, H.; Brown, G.M.

Characterization of Cell Types within a

Chorionic Gonadotropin-Secreting, Mechanically Dissociated Human Placental Cell Population in Perifusion Steele, G.L.; Currie, W.D.; Yuen, B.H.; Leung, P.C.K.

Changes in Circulating and Tissue Angiotensin II 166

during Acute and Chronic Stress

Yang, G; Xi, Z.-X.; Wan, Y.; Wang, H.; Bi, G.

Putative Melatonin Receptors in Peripheral Tissues

Editors: S.F. Pang (Hong Kong), MX. Dubocovich (Chicago, 111.) and G.M. Brown (Toronto)

Melatonin Receptors in Peripheral Tissues:

177

A New Area of Melatonin Research Pang, S.F.; Dubocovich, MX.; Brown, G.M.

Melatonin and Its Receptors in the Gastrointesti- 181

nal Tract

Lee, P.P.N.; Pang, S.F.

2-[ ${ }^{125}$ I]Iodomelatonin Binding Sites in the Rat 
Vas Deferens

Carneiro, R.C.G.; Markus, R.P.; Dubocovich, MX.

Presynaptic Modulation by Melatonin of the

199

Nicotine-Induced Calcium-Dependent Release of Norepinephrine from Rat Vas

Deferens Carneiro, R.C.G.; Markus, R.P.; Dubocovich, MX.

$\left[{ }^{125}\right.$ I] Iodomelatonin Binding Sites in Mammalian 207

and Avian Kidneys

Song, Y.; Ayre, E.A.; Pang, S.F.

Vascular Melatonin Receptors

221

Viswanathan, M.; Laitinen, J.T.; Saavedra, J.M.

$2-\left[{ }^{125}\right.$ I]Iodomelatonin Binding Sites in the Lung and Heart: A Link between the Photoperiodic Signal, Melatonin, and the Cardiopulmonary System

Pang, C.S.; Brown, G.M.; Tang, P.L.; Cheng, K.M.;

Panc SF.

No. 5

No. 6

Calcium-Signalling in Smooth Muscle: Recent Developments Guest Editor C.-Y. Kwan (Hong Kong)

Stretch-Induced Contraction and $\mathrm{Ca}^{2+}$ Mobiliza- 241 tion in Vascular Smooth Muscle Nakayama, K; Tanaka, Y.

Different $\mathrm{Ca}^{2+}$-Sensitivity in Phasic and Tonic 253 Types of Smooth Muscles Ozaki, H.; Karaki, H.

Influence of Internal Calcium Stores on Calcium- 263 Activated Membrane Currents in Smooth Muscle Low, A.M.; Lang, R.J.; Daniel, E.E.

Cross Talk between Plasma Membrane and Sarcoplasmic Reticulum in Canine Airway Smooth Muscle Bourreau, J.-P.

Identification of $\mathrm{Ca}^{2+}$-Release Channels in Smooth Muscle and Isolated Membranes

Zhang, Z.-D.; Kwan, C.-Y.; Daniel, E.E.

Use of Calcium Pump Inhibitors in the Study of 293 Calcium Regulation in Smooth Muscle Darby, P.J.; Kwan, C.-Y; Daniel, E.E.

Calcium Regulation and Contractile Dysfunction 305 of Smooth Muscle Sakai, Y.; Kwan, C.-Y

Review

Thyroid Growth-Stimulating and Growth-

Inhibiting Factors

Lewiriski, A.; Pawlikowski, M; Cardinali, D.P.

Original Papers

Effects of Corticosteroids on Cytosolic Free 352

Calcium Concentration of the Rat Adrenal Zona Glomerulosa Cell Yamaguchi, K; Habara, Y.; Warashina, A.; Kanno, T.

Plasma 6-Hydroxymelatonin, 6-Sulfatoxymela- 359 tonin and Melatonin Kinetics after Melatonin Administration to Rats

Raynaud, F.; Mauviard, F.; Geoffriau, M.; Claustrat, B.; Pevet, P.

367368369

Announcement Author Index Subject Index 
S. Karger

Medical and Scientific Publishers Basel • Freiburg • Paris • London New York $\square$ New Delhi • Bangkok

Singapore $\cdot$ Tokyo $\bullet$ Sydney

Drug Dosage

The authors and the publisher have exerted every effort to ensure that drug selection and dosage set forth in this text are in accord with current recommendations and practice at the time of publication. However, in view of ongoing research, changes in government regulations, and the constant flow of information relating to drug therapy and drug reactions, the reader is urged to check the package insert for each drug for any change in indications and dosage and for added warnings and precautions. This is particularly important when the recommended agent is a new and/or infrequently employed drug.

All rights reserved.

No part of this publication may be translated into other languages, reproduced or utilized in any form or by any means, electronic or mechanical, including photocopying, recording, microcopying, or by any information storage and retrieval system, without permission in writing from the publisher or, in the case of photocopying, direct payment of a specified fee to the Copyright Clearance Center (see 'Information for Readers and Subscribers').

(C) Copyright 1993 by S. Karger AG, P.O. Box, CH-4009 Basel (Switzerland) Printed in Switzerland on acid-free paper by Thiir AG Offsetdruck, Pratteln

I. IV

Contents 